\title{
Assessing Corporate Brand Equity of Public Universities
}

\author{
SHUHAIDA MD NOOR \\ Universiti Sains Malaysia \\ KAMARUZZAMAN ABDUL MANAN \\ International Islamic University Malaysia \\ HAJA MYDIN ABDUL KUTHOOS \\ Universiti Sains Malaysia
}

\begin{abstract}
Brand equity studies focus heavily on the brands of profit-based organisations. Similarly in Malaysia, while there have been a number of studies on leading brands owned by profit-based organisations (e.g. Petronas, Air Asia and Maxis), few studies have explored branding in relation to not-for-profit organisations, such as public universities. Public universities tend not to place too high a priority on their brand development because they often lack an understanding of the significance of brand equity. The increased pressure on public universities to compete in the highly competitive higher education market, however, is slowly changing this perception. Therefore, this study will offer some preliminary insights into the dimensions contributing to the corporate brand equity of a public university in Malaysia, Universiti Sains Malaysia (USM). This study illustrates how metrics can be used to assess the brand of a public research university and can facilitate the development of corporate brand equity metric for institutions of higher education. Data collection was conducted using the survey method, distributing questionnaires to 400 students from eight local public universities. The findings of this study indicate that the dimensions of awareness, quality of service, trust and relevance have a positive relationship with USM's corporate brand equity. These findings may help to guide future researchers in understanding the dimensions of brand equity in relation to public universities.
\end{abstract}

Keywords: Branding, brand equity, university, Universiti Sains Malaysia, higher education institution.

\section{INTRODUCTION}

Political and economic forces have pushed Malaysian public universities to become increasingly financially independent and more competitive amidst a vibrant Malaysian education market (Taib \& Abdullah, 2016). Much of the academic standing of public universities, and consequently their economic power, rests in their capacity to attract undergraduate and postgraduate students. Notwithstanding, with over 65,000 applicants each year vying for placement in one of 20 public universities (Rohaniza Idris, 2016) and more than 53 private universities (Malaysian Qualifications Agency, 2018), attracting these potential students has become increasingly challenging.

As the market becomes increasingly competitive, branding has emerged as an important heuristic in which to signal the added values that differentiate one university from another (Erdem \& Swait, 1998, 2016; Hemsley-Brown, Melewar, Nguyen \& Wilson, 2016; Iqbal, Rasli \& Hassan, 2012; Javani, 2016; Joseph, Mullen \& Spake, 2012; Sultan \& Yin Wong, 2012). In marketing terms, according to Keller (2003, 2016), these added values constitute the university's brand equity and determine the university's ability to command market responses, such as choice of enrolment, endorsements and ability to demand a 
premium on student fees. For example, despite the university's strict entry requirements, higher fees or remote location, students will be inherently drawn to a university with strong brand equity, selecting that university over another with lower equity.

Research shows that brand equity is a multidimensional concept (Aaker, 2014; Davcik, Vinhas da Silva \& Hair, 2015; Keller, 2013); consequently, brand equity should be assessed based on a set of key brand equity dimensions (Davcik et al., 2015; Lehmann, Keller, \& Farley, 2008; Reynolds \& Phillips, 2005). It is important to identify the various dimensions of a university's brand equity in order to establish its strategic marketing direction (Haja Mydin, Shuhaida, Nor Hazlina \& Kamaliah, 2014; Pinar, Trapp, Girard \& Boyt, 2014). These metrics can help to explain the overall strength or health of the brand, and more importantly, will allow the market strategist to identify whatever dimensions might require further attention, as well as those dimensions that can be leveraged upon for a particular brand (Md Noor, Styles \& Cowley, 2011). Brands within a similar product range might have similar overall strength but may differ on the dimensions. For example, two research universities may have similar brand equity, but differ in terms of the dimensions of their perceived quality and relevance. As such, a university low in perceived quality and relevance can subsequently take action to improve its relevance to its target audience.

This research provides some preliminary insights into the key dimensions of brand equity in relation to a public research university ( $R U$ ) from the perspective of an important key stakeholder group: students. This study has focused on public RUs in light of the unique challenges that RUs face in Malaysia with respect to defending their academic reputation while seeking to attain global recognition. For these universities, it is not only imperative that they attract the numbers, but that they attract the right quality of students to help maintain their RU status.

The research was conducted as part of a larger effort to identify the brand equity of Universiti Sains Malaysia (USM). While these efforts might be useful for revealing how metrics are used to assess the brand of a public RU, this study has wider implications, being a point of departure for the development of brand equity metrics for institutions of public higher education. USM is one of Malaysia's five public universities that have been conferred RU status. With this recognition comes the pressure to continuously improve the university's quality and reputation with the aim of improving Malaysia's standing in the global higher education market. USM has also conferred the Accelerated Programme of Excellence in 2008 due to its clear vision in setting its academic direction. Consequently, USM has embarked upon a branding initiative with the aim of increasing its national and global visibility as a reputable institution of higher education (Dzulkifli, Ramli, Shuhaida \& Ming, 2010).

\section{University Corporate Brand Equity}

Despite some initial reservations to the idea of the marketisation of education (Furedi, 2011; Newman \& Jahdi, 2009), an increasing number of universities are now emulating corporate marketing strategies as means of ensuring their competitiveness and sustainability (Bennett \& Ali-Choudhury, 2009; Chapleo, 2015; Iqbal et al., 2012; Joseph et al., 2012; Sultan \& Yin Wong, 2014). One of the hallmarks of marketing is branding-a marketing activity that involves the process of creating or enhancing the value of a brand in the mind of consumers and communicating that value to the target market. A good branding strategy incorporates various modes of value creation, from product development (e.g. ensuring the relevance of academic offering), all the way through to product delivery 
(e.g. providing a conducive academic environment) and nation-building (e.g. community and research networks, community and national services, etc.).

The ultimate aim in branding is to create strong corporate brand equity, that is, the differential effects that a brand has on the marketing of brand (Keller, 2003, 2013). A brand with strong equity is easily recognisable and recalled, and importantly, creates a distinction strong enough to generate favourable response towards the brand (Keller, 2013). In the case of universities, a strong corporate brand will ensure that it stays top of mind when higher education is mentioned and will garner top choice or aspiration when it comes to continuing ones' education or endorsement to others. In effect, a university with strong brand equity has a brand that is of value to its customers.

Notwithstanding, a distinction must be made between financial-based brand equity (FBBE) as a measure of business performance, and customer-based brand equity (CBBE) as a measure of the impact of marketing activities on consumers (Md Noor et al., 2011). The consensus is that the value of a brand ultimately resides in the minds of consumers, which eventually translates into financial value for the owner of that brand. Consequently, what consumers perceive as the value may differ from what the brand owner intends to offer.

Driven by the needs to understand the effects of branding in the minds of consumers, researchers have endeavoured to a better understanding of the sources of brand value for consumers. In general, research indicates values arise out of what people think and feel about a brand or 'what's in people's head about the brand' (Ambler, 2003, p. 46), which is a function of consumers' knowledge about the brand (Keller, 2013). This understanding has led to the development of various corporate brand equity metrics that encapsulate dimensions reflecting consumers' thoughts and feelings about brands. Common dimensions found in corporate brand equity metrics include brand awareness, brand loyalty, brand liking, brand relevance, perceived brand quality and positive brand associations (Lehmann et al., 2008; Md Noor et al., 2011). Nonetheless, specific metrics have been developed and used to provide more specific directions. It has been argued that university branding differs from other commercial brands due to cultural issues, branding frameworks and architecture (Chapleo, 2015). As such, it follows that measuring corporate brand equity should also be based on dimensions that pertinent to the values of its target market.

Previous research has shown that university corporate brand equity is multidimensional (Haja Mydin et al., 2014; Pinar et al., 2014). This research investigates four dimensions thought to be fundamental to the corporate brand equity of RUs: awareness, perceived quality, trustworthiness and relevance. Figure 1 presents the hypothetical model for this study. 


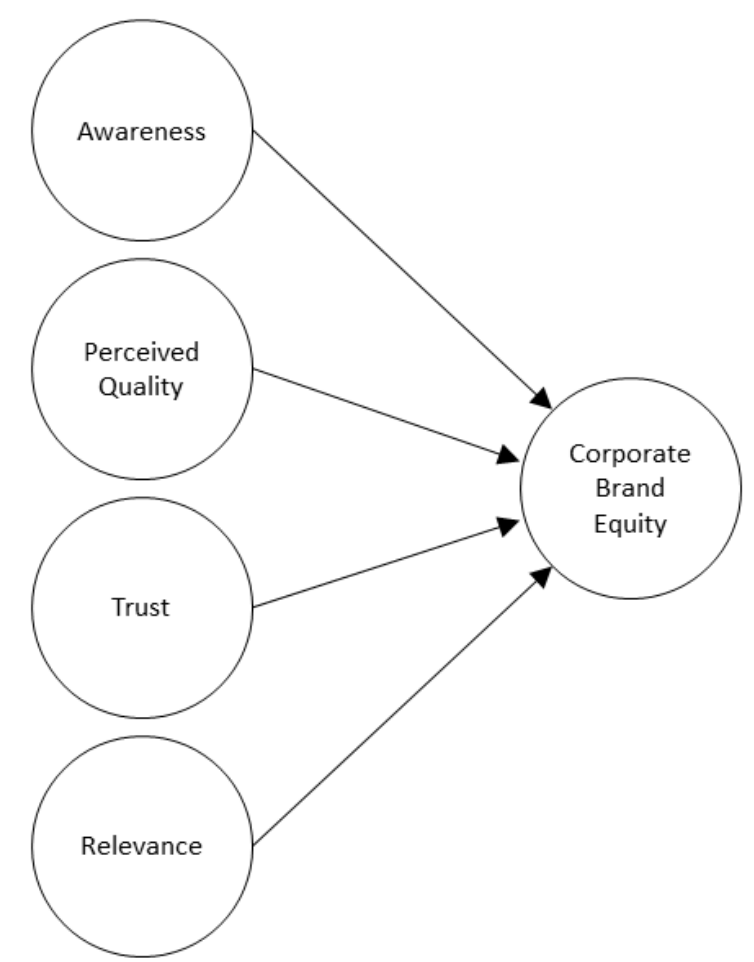

Figure 1: Key dimensions of the university's corporate brand equity

\section{Hypotheses}

The dependent variable in this study, brand equity, is adapted from Keller $(2003,2013)$ and is defined as the differential effects of a university's brand knowledge on consumers' responses to the university's marketing of its corporate brand. It is important to note that a university brand only possesses equity when it makes a difference in consumers' responses. Such responses should have strength and direction; in other words, consumers can have either a strong or weak response to a brand in either positive or negative directions. For example, while consumers might react positively to two brands, they will inevitably choose the brand with stronger corporate brand equity over the other competitive brand.

The four independent variables in this study-awareness, perceived quality, trustworthiness and relevance-represent how the consumer thinks and feels about the brand in light of their knowledge of the brand. These dimensions are a function of consumers' experiences with the brand, through word of mouth, advertisements or media exposure, as well as direct (e.g. having been a student) or indirect (e.g. participation in focal university activities) experiences. As such, our research hypotheses have been developed based on these independent variables.

Awareness refers to the ability of consumers to identify the brand and the meaning that it represents (Keller, 2013). Awareness is considered fundamental to corporate brand equity as it indicates whether or not the brand exists in the consumers' memory; therefore, awareness is thought to be one of the key constituents of corporate brand equity. The meaning that the consumer attributes to the corporate brand arises out of the associations that the consumer makes with the brand, such as USM being linked to 'APEX status', 'a university in Penang' or 'a research university'. Awareness occurs when memories of the corporate brand are triggered by cues in the environment or in the consumer's mind. For example, a consumer may think about the word APEX or a cue that they have observed in their environment, which subsequently activates their memory of USM being both an APEX 
and a RU university in Penang. Increasing awareness of the university brand, therefore, should increase the differential effects of the brand. As such, a university with low or zero awareness will garner low to no response. Thus, the following hypothesis is proposed:

\section{H1: University brand awareness has a positive influence on its corporate brand equity}

Perceived quality is identified as consumers' evaluation of overall quality or superiority of a product or service compared to the alternatives and in relation to its intended purpose (Keller, 2003). Quality has historically been simultaneously the raison de'etre and the sine qua non of higher education (Jarvis, 2014; Teeroovengadum, Kamalanabhan \& Seebaluck, 2016); this is particularly true today where universities are constantly being monitored, measured and regulated based on various quality standards (Jarvis, 2014). Quality standards, such as national quality frameworks and various international university rankings, have become an important source of influence on the public's overall perception of the quality of a university. Evaluations of quality are based on diverse elements, such as the quality of programmes, teaching faculty and student services. Of these, the perceived quality of faculty has been found to be the most important dimension of a university's corporate brand equity (Pinar et al., 2014). Other than a set of quality standards, this perception of quality may also come from other images formed based on other proxy measures such as its heritage, past achievements and reputation. Research shows that when it comes to selecting public universities, quality education and accreditation are particularly important (Iqbal et al., 2012; Joseph et al., 2012). Therefore, the following hypothesis is offered:

H2: Perceived quality of a university brand has a positive influence on its corporate brand equity

Trust is defined as consumers' confidence in the brand's intentions and reliability (Delgado- Ballester \& Munuera-Alemán, 2005). A strong brand is a brand that consumers can trust, especially when the consumer is considering a long-term relationship with the brand, such as enrolling in a university or partaking in research initiatives. Additionally, brand trust is important when recommending a university to others. Trust helps to alleviate fears and increases the expectation of positive outcomes. Trust also provides necessary assurances that consumers are unlikely to be exploited by the corporate brand. Trust contributes to and results in a better explanation of corporate brand equity (DelgadoBallester \& Munuera-Alemán, 2005). Specifically, student trust has been shown to play an important role in the marketability of a university's corporate brand and its programmes, and to the perception of university performance (Sultan \& Yin Wong, 2012, 2014). As such, the following hypothesis is proposed:

\section{H3: University brand trust has a positive influence on its corporate brand equity}

In a highly competitive market, a high quality, strong brand with high visibility and an exceptional level of trust might still perish should it becomes irrelevant to its target market. Brand relevance is a function of the brand's ability to fulfil consumer expectations in a specific category or subcategory and to be able to compete with other brands in that 
category (Aaker, 2004). However, as a market becomes increasingly competitive, the brand also needs to differentiate itself sustainably through the provision of offerings in new categories or subcategories (Aaker, 2010). Needless to say, consumers have to be in the market for these new offerings. In the increasingly competitive higher education market, a university's corporate brand must ensure that it stays relevant, offering, for example, academic programmes that are consistent with current developments in technology or society. In particular, in light of disruptive technologies, there has been a call of late for traditional universities to change their DNA and to innovate to ensure that they stay relevant (Christensen \& Eyring, 2011). A study by Joseph et al. (2012) indicates that both private and public university students today seek up-to-date university experiences that offer the latest in technology, community involvement and an appealing campus environment. Thus, the following hypothesis is proposed:

H4: University brand relevance has a positive influence on its corporate brand equity

\section{Research Sample}

\section{METHODOLOGY}

The target population for this study includes students of public universities in Malaysia. Dzulkifli Abdul Razak et al. (2010) identified university students among 11 major groups of university stakeholders. According to statistics released by the Ministry of Finance Malaysia (2017), the number of students enrolled in public universities in 2017 was estimated to be 540,113 . Krejcie and Morgan (1970) suggest that for a population of 100,000 , the ideal sample should be 384 . The sampling ratio at this level is such that the confidence level is $95 \%$ and the sampling error is $5 \%$ (Krejcie \& Morgan, 1970). In this study, we draw upon a sample of 400 students, with this figure being slightly higher than the recommended 384 . We determined this larger sample size after considering the possibility of insufficient data due to missing values and an incomplete questionnaire.

Purposive sampling was used for data collection due to budgetary and time limitations. Data was collected from students of eight public universities after having sought permission for data to be collected from their students. These students were selected due to their prior experience and knowledge in selecting public universities for pursuing higher education. Data were collected from 50 currently enrolled students at each participating university.

\section{Survey Method}

Following Lehmann et al. (2008) and similar studies of university branding (e.g. Binnie, 2008; Gray, Shyan Fam, \& Llanes, 2003), this study used the survey method. Question items for the survey were developed based on past literature (Haja Mydin, 2013; Haja Mydin et al., 2014; Lehmann et al., 2008), but modified to include dimensions pertinent to university corporate branding. Items for the dependent variable, corporate brand equity, were identified from Keller $(2003,2013)$, while items for the independent variables were identified from Lehmann et al. (2008), but were modified to suit university brands. The survey questionnaire was divided into three parts. The first section of the questionnaire explained the purpose of the study and provided assurances with respect to confidentiality. This section also expressed gratitude for respondents' willingness to participate in the study. The second section of the questionnaire was the demographic section, collecting details such as the participant's gender, ethnicity, education level and academic stream. The third 
section of the questionnaire contained questions on the independent and dependent variables. Data collection procedures resulted in the return of 395 fully completed questionnaires.

\section{Research Procedure}

The questionnaire was developed in the Malay language, the native language of the majority of participants in this study. The choice of the Malay language over English was determined to facilitate accurate responses by the respondents to the questionnaire. After having sought permission from the administration of participating universities, individual students approached and informed about the purpose of the study. Those students who consented to participate completed the questionnaires in the presence of an administrator who was on hand to answer any questions that the students might have had. Data collection was completed over the course of 2 weeks.

\section{RESULTS}

In testing the hypotheses, the study employed the Partial Least Squares (PLS) analysis using SmartPLS 3.0 software (Ringle, Wende, \& Becker, 2015). Anderson and Gerbing (1991) recommend a two-stage analytical procedure. Thus, we began the analysis with a test of the measurement model (i.e. validity and reliability of the measures), followed by structural model testing (i.e. testing the hypothesised relationships) (Ramayah, Lee \& In, 2011). In addition, the bootstrapping method with 5000 resample's was used to test the significance of the path coefficients and the loadings (Hair, Hult, Ringle \& Sarstedt, 2014).

\section{Respondent Demographics}

Tables 1-5 provide a detailed analysis of the demographics of respondents in this study. Suffice to say, the sample of 395 Malaysian university students reflects many of the demographic trends consistent across most Malaysian public universities. The majority of the sample was female (Table 1), reflecting a slight female bias in student enrolments. Similarly, over three-quarters of the sample were ethnic Malays (87.3\%), followed by Indians, Chinese and smaller ethnic groups (Table 2). Almost all (91.9\%) respondents were enrolled in bachelor degree courses, although less than $10 \%$ were enrolled in diploma programmes (Table 3). This reflects the situation universities in Malaysia where the majority of university programmes are in fact bachelor degree programmes. More than half $(60 \%)$ of the respondents had been enrolled in an academic science stream in high school before commencing their university studies (Table 4). In this study, we attempted to sample students from both science and art academic stream. As previously indicated, this study relies on a sample of 395 student respondents from eight Malaysian public universities. Fifty samples were selected from each university; however, only 45 respondents from UTeM completed the questionnaire (Table 5).

Table 1: Respondents by gender

\begin{tabular}{lcc}
\hline Gender & Number & Percentage (\%) \\
\hline Male & 179 & 45.3 \\
Female & 216 & 54.7 \\
Total & 395 & 100 \\
\hline
\end{tabular}


Table 2: Respondents by ethnicity

\begin{tabular}{lcc}
\hline Ethnicity & Number & Percentage (\%) \\
\hline Malay & 345 & 87.3 \\
Chinese & 12 & 3 \\
Indian & 29 & 7.3 \\
Others & 9 & 2.4 \\
Total & 395 & 100 \\
\hline
\end{tabular}

Table 3: Respondents by level of education

\begin{tabular}{lcc}
\hline Education Level & Number & Percentage (\%) \\
\hline Degree & 363 & 91.9 \\
Diploma & 32 & 8.1 \\
Total of Respondents & 395 & 100 \\
\hline
\end{tabular}

Table 4: Respondents by academic stream

\begin{tabular}{lcc}
\hline Academic Stream & Number & Percentage (\%) \\
\hline Arts Stream & 158 & 40 \\
Science Stream & 237 & 60 \\
Total of Respondents & 395 & 100 \\
\hline
\end{tabular}

Table 5: Respondents by university

\begin{tabular}{lcc}
\hline University & Number of Respondents & Percentage (\%) \\
\hline UniMAP & 50 & 12.7 \\
UIAM & 50 & 12.7 \\
UPM & 50 & 12.7 \\
UM & 50 & 12.7 \\
USIM & 50 & 12.7 \\
UKM & 50 & 12.7 \\
UPNM & 50 & 12.7 \\
UTeM & 45 & 11.4 \\
Total & 395 & 100 \\
\hline
\end{tabular}

\section{Partial Least Squares (PLS) Analysis}

Tests of the validity and reliability of the measurements were conducted before proceeding to path analysis to test the hypotheses.

\section{a) Goodness of Measures}

Validity and reliability were used to test the goodness of the measures. Table 6 explains the goodness-of-fit measure employed in this study. Reliability analysis was used to test how consistently a measuring instrument measures the concepts used in this study. Validity analysis, on the other hand, has been used to test how well the developed instrument measures the concepts (Sekaran \& Bougie, 2010).

Table 6: Goodness-of-fit measures

\begin{tabular}{lc}
\hline Types of Fitness Value & Acceptable Value of Fitness \\
\hline Factor Loading & Acceptable if greater or equal to $0.50^{* *}$ \\
Composite Reliability & Acceptable if greater or equal to $0.70^{* *}$ \\
Average Variance Extracted (AVE) & Acceptable if greater or equal to $0.50^{* *}$ \\
Discriminant validity & Correlation value must not be greater than $0.90^{* *}$ \\
Q2 & The value must greater than 0.0 to predict \\
\hline
\end{tabular}

*Source: Hair, Black, and Babin (2010) 


\section{b) Construct Validity}

PLS analysis begins with construct validity analysis. This analysis was used to assess how well the results obtained from the measure fit the theories and study (Sekaran \& Bougie, 2010). This can be examined through convergent and discriminant validity analysis.

Figure 2 presents the factor loading and cross-loadings in the research construct model. Firstly, we looked at each factor loading and its cross-loadings to determine whether there were any loading below the cut-off value 0.5 (Hair et al., 2010). Table 7 shows that all items used to measure the research constructs were highly loaded, thus confirming construct validity.

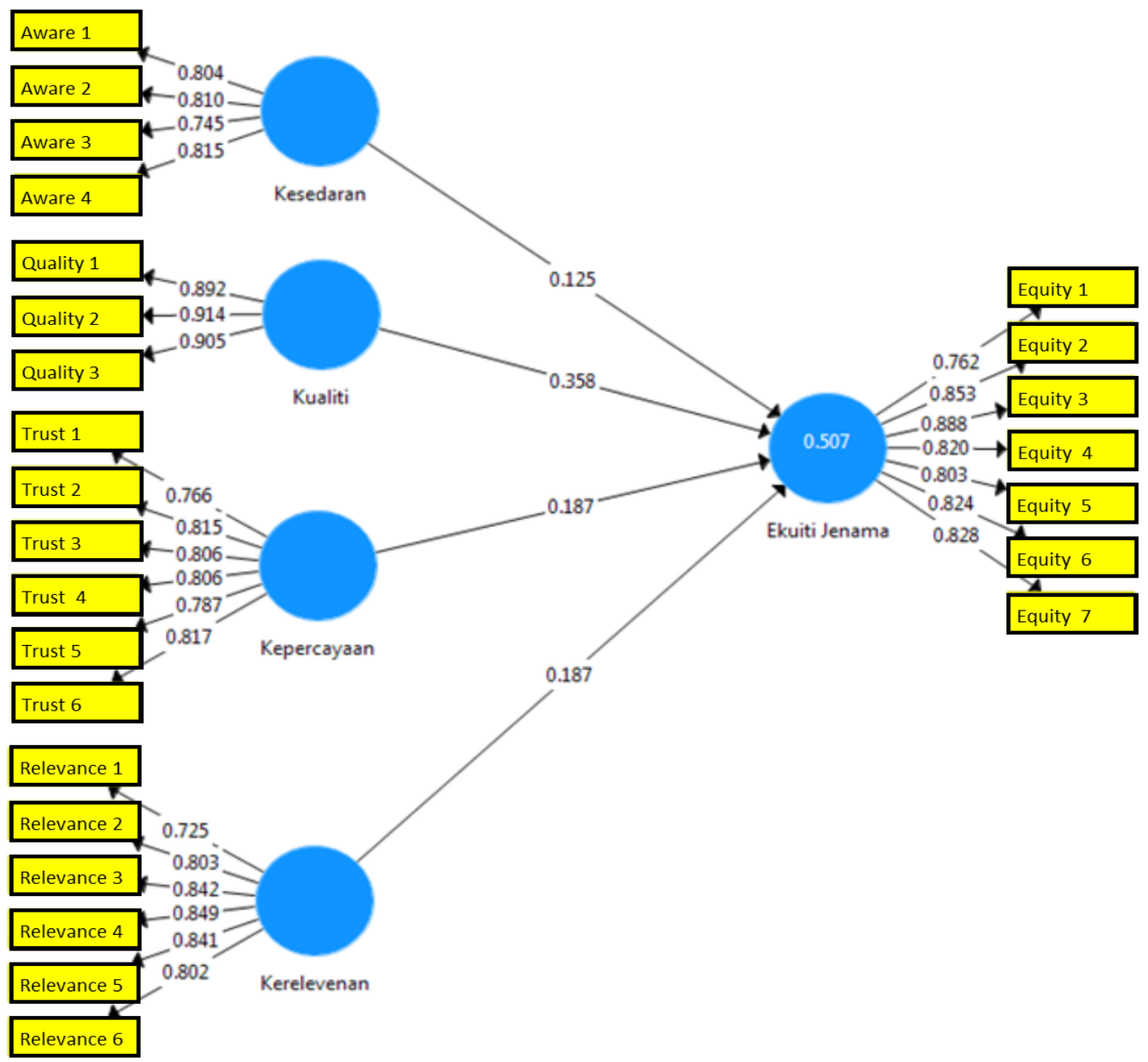

Figure 2: Research construct model

Table 7: Results of measurement model

\begin{tabular}{llccc}
\hline Model Construct & Measurement Item & Loading & $\begin{array}{c}\text { Composite } \\
\text { Reliability }\end{array}$ & Average Variance Extracted (AVE) \\
\hline Brand Trust & Trust1 & 0.766 & 0.914 & 0.640 \\
& Trust2 & 0.815 & & \\
& Trust3 & 0.806 & \\
& Trust4 & 0.806 & \\
& Trust5 & 0.787 & \\
& Trust6 & 0.817 & \\
\hline
\end{tabular}




\begin{tabular}{|c|c|c|c|c|}
\hline \multirow[t]{3}{*}{ Perceived Quality } & Quality1 & 0.892 & 0.930 & 0.817 \\
\hline & Quality2 & 0.914 & & \\
\hline & Quality3 & 0.905 & & \\
\hline \multirow{7}{*}{$\begin{array}{l}\text { Corporate Brand } \\
\text { Equity }\end{array}$} & Brand1 & 0.762 & 0.938 & 0.683 \\
\hline & Brand2 & 0.853 & & \\
\hline & Brand3 & 0.888 & & \\
\hline & Brand4 & 0.820 & & \\
\hline & Brand5 & 0.803 & & \\
\hline & Brand6 & 0.824 & & \\
\hline & Brand7 & 0.828 & & \\
\hline \multirow[t]{6}{*}{ Brand Relevance } & Relevance1 & 0.725 & 0.920 & 0.658 \\
\hline & Relevance2 & 0.803 & & \\
\hline & Relevance3 & 0.842 & & \\
\hline & Relevance4 & 0.849 & & \\
\hline & Relevance5 & 0.841 & & \\
\hline & Relevance6 & 0.802 & & \\
\hline \multirow[t]{4}{*}{ Brand Awareness } & Aware1 & 0.804 & 0.872 & 0.631 \\
\hline & Aware2 & 0.810 & & \\
\hline & Aware3 & 0.745 & & \\
\hline & Aware4 & 0.815 & & \\
\hline
\end{tabular}

Average variance extracted $(\mathrm{AVE})=$ (summation of the square of the factor loadings $) /\{$ (summation of the square of the factor loadings) + (summation of the error variances)\}

Composite reliability $(C R)=$ (square of the summation of the factor loadings $) /\{($ square of the summation of the factor loadings) + (square of the summation of the error variances)\}

The analysis continues with an analysis of convergent validity. This analysis aims to determine the degree to which multiple items are in fact measuring the same or similar concepts. A combination of factor loadings, composite reliability and average variance extracted (AVE) were used to assess convergence validity (Hair et al., 2010). Factor loadings ranged from $0.914-0.725$. Moreover, composite reliability values ranged from $0.872-0.938$. This result exceeded the value for significance, which was 0.7. Finally, AVE was used to examine measurement error. The results for AVE ranged 0.631-0.817, again exceeding the recommended value of 0.5 . Thus, all five independent variables-awareness, service quality, trust, relevant and corporate brand equity-were determined to represent valid measures of their respective constructs based on their parameter estimates and statistical significance (Chow \& Chan, 2008).

\section{c) Discriminant Validity}

The second analysis of construct validity involves discriminant validity testing. Here, the aim is to determine the degree to which items differentiate among constructs or measure distinct concepts. This was assessed by examining the correlations between the measures. High AVE items should load more strongly on their own constructs in the model, thus ensuring there are no potentially overlapping constructs (Ramayah et al., 2011). As shown in Table 8, the squared correlation for the value of each research construct is less than its AVE. This indicates that the construct has adequate discriminant validity. Therefore, based on two construct validity analyses, the findings conclude that the measurement model demonstrates adequate convergent and discriminant validity. 


\begin{tabular}{|c|c|c|c|c|c|c|}
\hline & & & & & & \\
\hline Varla & & 1 & 2 & 3 & 4 & 3 \\
\hline 1 & Brand Equity & 0.826 & & & & \\
\hline 2 & Trust & 0.593 & 0.800 & & & \\
\hline 3 & Relevance & 0.524 & 0.515 & 0.811 & & \\
\hline 4 & Awareness & 0.526 & 0.579 & 0.466 & 0.794 & \\
\hline 5 & Service Quality & 0.649 & 0.663 & 0.511 & 0.576 & 0.904 \\
\hline
\end{tabular}

Diagonals (in bold) represent the average variance extracted while the other entries represent the squared correlations.

\section{d) Reliability Analysis}

The analysis proceeds to examine the consistency of the instrument in measuring the concepts based on Cronbach's alpha coefficient. This analysis aims to assess the inter-item consistency of the measurement items. Table 9 summarises the loadings and alpha values. The result indicates that all alpha values are above the cut-off point for significance, which according to Nunnally and Bernstein (1994), is 0.6. The results for composite reliability ranged from 0.805-0.922. According to Fornell and Larcker (1981), the composite reliability value should be more than 0.7 . As such we can conclude that the research instrument is reliable.

Table 9: Results of reliability testing

\begin{tabular}{lc}
\hline Constructs & Cronbach's Alpha $(\boldsymbol{\alpha})$ \\
\hline Trust & 0.887 \\
Service Quality & 0.888 \\
Brand Equity & 0.922 \\
Relevance & 0.896 \\
Awareness & 0.805 \\
\hline
\end{tabular}

e) Hypotheses Testing

After confirming the model's validity and reliability, path analysis was conducted. This analysis was conducted to test the four research hypotheses. Figure 3 presents the results of hypothesis testing; (a) $b$ and $R^{2}$ values, (b) $t$-values. In addition, Table 10 summarises the overall results of hypothesis testing. 


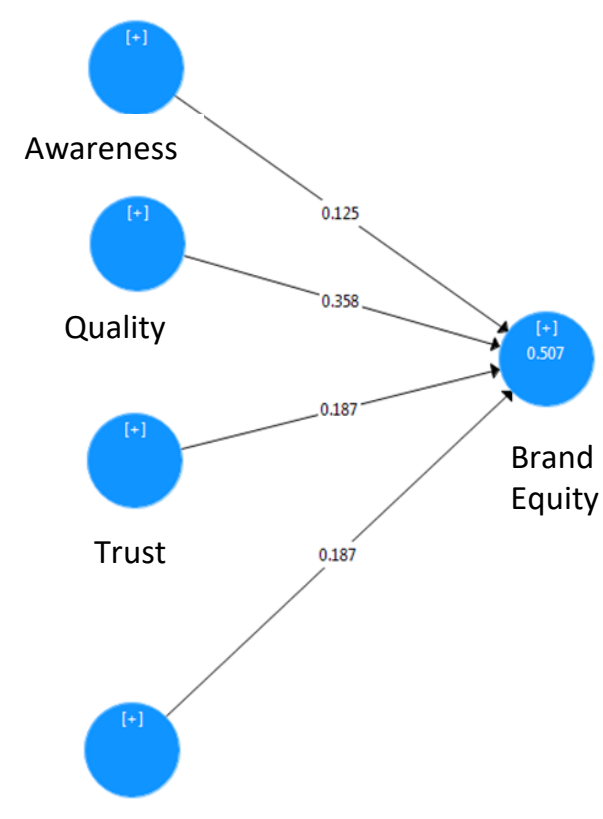

Relevance

(a.)

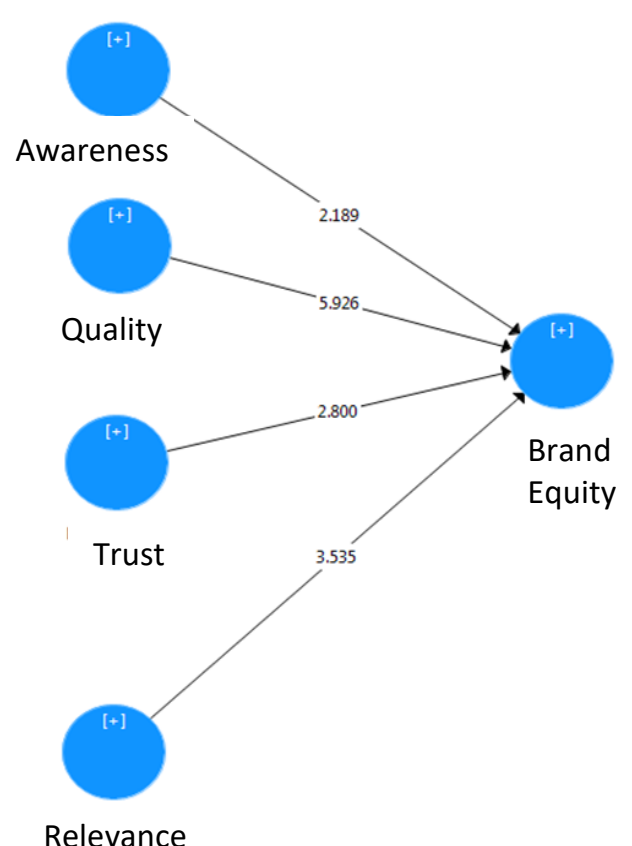

(b.)

Figure 3: Results of hypothesis testing: (a) 8 values and $R^{2}$, (b) $t$-values

Table 10: Path coefficients and hypothesis testing

\begin{tabular}{|c|c|c|c|c|c|c|c|c|c|}
\hline Hypothesis & Relationship & $\begin{array}{c}\text { Std } \\
\text { Beta }\end{array}$ & $\begin{array}{l}\text { Std } \\
\text { Error }\end{array}$ & $t$ & $p$ & Decision & $f^{2}$ & $R^{2}$ & $Q^{2}$ \\
\hline $\mathrm{H} 1$ & $\begin{array}{l}\text { Awareness } \rightarrow \\
\text { Corporate } \\
\text { Brand Equity }\end{array}$ & 0.125 & 0.057 & 2.189 & 0.029 & Supported & 0.018 & 0.507 & 0.320 \\
\hline $\mathrm{H} 2$ & $\begin{array}{l}\text { Service Quality } \\
\rightarrow \text { Corporate } \\
\text { Brand Equity }\end{array}$ & 0.358 & 0.060 & 5.926 & 0.000 & Supported & 0.126 & & \\
\hline H3 & $\begin{array}{l}\text { Trust } \rightarrow \\
\text { Corporate } \\
\text { Brand Equity }\end{array}$ & 0.187 & 0.067 & 2.800 & 0.005 & Supported & 0.034 & & \\
\hline $\mathrm{H} 4$ & $\begin{array}{l}\text { Relevance } \rightarrow \\
\text { Corporate } \\
\text { Brand Equity }\end{array}$ & 0.187 & 0.053 & 3.535 & 0.000 & Supported & 0.047 & & \\
\hline
\end{tabular}

The $R^{2}$ value of 0.507 suggests that $50.7 \%$ of the variance in brand equity can be explained by awareness, perceived quality, trust and relevance. A closer look shows that perceived quality was the most significant contributor $(B=0.358, t=5.926, p=0.000)$ to $\mathrm{CBE}$, followed by brand relevance $(B=0.187, t=3.535, p=0.000)$, brand trust $(\theta=0.187, t=$ $2.800, p=0.005)$ and brand awareness $(B=0.125, t=2.189, p=0.029)$. As for the overall model prediction, as suggested by Ramayah et al. (2011), in order for the model to be considered valid for predicting the corporate brand equity of USM, the $Q^{2}$ value needs to be greater than 0.0 . In this study, the $Q^{2}=0.320$, indicating that the model is valid to predict USM's brand equity. Therefore, based on the path analyses, the results indicate that $\mathrm{H} 1, \mathrm{H} 2$, $\mathrm{H} 3$ and $\mathrm{H} 4$ in this study are supported. 


\section{DISCUSSION AND CONCLUSION}

This study highlights the importance of branding as a powerful tool for public universities in Malaysia. The increase in client intellectual capacity in the 21st century has changed the way in which universities respond to the demand to deliver knowledge (Kamaruzzaman \& Che Mahzan, 2017). The advancement of knowledge and technology has led to the academic world becoming more competitive and complex. Each year, thousands of universities compete to claim their position among the best educational service provider (QS World University Rankings, 2018). Two of the main QS indicators used to determine university rankings include academic reputation and employer reputation. Therefore, brand equity is an important asset that needs to be developed and managed because it represents clients' perceptions of the service and the benefits it provides.

This study was undertaken to understand the factors that contribute to the brand equity of USM. The results of the PLS analysis establish that all four factors (i.e. brand trust, perceived quality, brand relevance and brand awareness) play a significant role in the development of USM's brand equity. The findings of the factor loadings for all items on the five constructs, composite reliability, AVE, Cronbach's alpha and construct reliability values were all above the recommended levels (Hair et al., 2010). As such, these results indicate that the model developed for this study was reliable. In addition, the path analysis confirmed that the model was also valid to predict USM's brand equity.

Being a top 100-world class university, however, USM must take into consideration the perceived value that its stakeholders recognise in its offerings. This argument is consistent with these research findings, with respondents being emphatic that the perceived quality of the educational services provided by USM is the most important factor contributing to the university's corporate brand equity. As an APEX university, USM's stakeholders expect the university to provide the best offerings in the country. Therefore, congruent with the USM tagline, we lead, the university has an obligation to ensure that the services and products being provided are superior to those being offered by other public universities. Not with standing, various economic factors have resulted in government funding for public higher education having being incrementally reduced over recent years. As such, funding is increasingly guided by the performance of public universities. Therefore, in order to remain relevant, USM must ensure that its corporate brand consistently inspires the market for enrolment, patronage and stewardship. Respondents highlighted that brand relevance was the second major factor contributing to the development of USM's brand equity. Therefore, USM must continue to explore new business models and target emerging markets to ensure that the university remains ahead of its competitors and relevant in fastchanging market.

Trust in the USM brand affects stakeholders' responses to the university's products and services. Trust is inspired by perceived reliability, honesty and value. The results confirm that trust in the brand contributes towards USM's corporate brand equity. Therefore, building stakeholders' trust should be part of USM's strategy in strengthening its brand equity. Brand trust is developed experientially. As such, USM must continue to ensure that its services and products are reliable and dependable if it is to maintain the trust of its stakeholders.

The results also indicate that stakeholders' awareness of the USM brand influences the university's brand equity. Therefore, USM must be consistent in upholding stakeholders' awareness of the university's products, services and their quality. Stakeholders are unlikely 
to respond positively to the USM brand as their first choice for higher education if they are unaware of the university's quality services or products.

In conclusion, in order for USM and other similar public RUs to develop strong corporate brand equity, it is important to emphasise perceived quality, brand relevance, trust as well as awareness. Prioritising these factors will be instrumental in developing future branding strategies. Finally, the results of this study indicate that any change in any one factor is likely to have a significant impact on USM's brand equity. Therefore, it is important for USM to take a holistic approach to its branding strategies, considering all the factors collectively.

\section{BIODATA}

Shuhaida Md Noor is a Senior Lecturer at the School of Communication, Universiti Sains Malaysia. Her research interest areas include customer-based brand equity, self-relevance in branding, branding of destinations and consumer memories. Email: shuhaida@usm.my

Kamaruzzaman Abdul Manan is an Assistant Professor in the Department of Communication at International Islamic University Malaysia. His research interest areas include electoral studies, social media, public relations, organisational communication and health communication. Email: kamarule@iium.edu.my

Haja Mydin Bin Abdul Kuthoos currently is doing PhD on Gender Studies at Centre for Research on Women and Gender (KANITA), Universiti Sains Malaysia. His research interests are in Branding, Brand Equity, Tourism, Crime and Juvenile Delinquency. Email: hajamydinusm@gmail.com 


\section{REFERENCES}

Aaker, D. A. (2004, Summer). The innovator's prescription: The relevance of brand relevance. Strategy+business, 35, 60-69.

Aaker, D. A. (2010). Brand relevance: Making competitors irrelevant. San Francisco, CA: Jossey-Bass.

Aaker, D. A. (2014). Aaker on branding: 20 principles that drive success. New York, NY: Morgan James.

Ambler, T. (2003). Marketing and the bottom line: The marketing metrics to pump up cash flow (2nd ed.). London, England: Prentice Hall.

Anderson, J. C., \& Gerbing, D. W. (1991). Predicting the performance of measures in a confirmatory factor analysis with a pretest assessment of their substantive validities. Journal of Applied Psychology, 76(5), 732-740. doi: 10.1037/0021-9010.76.5.732

Bennett, R., \& Ali-Choudhury, R. (2009). Prospective students' perceptions of university brands: an empirical study. Journal of Marketing for Higher Education, 19(1), 85107. doi: 10.1080/08841240902905445

Binnie, C. (2008). Constructing university brands through university research magazines (Master's Thesis, University of Ottawa, Ottawa, Canada). Retrieved from http://citeseerx.ist.psu.edu/viewdoc/download?doi=10.1.1.455.5182\&rep=rep1\&typ $\mathrm{e}=\mathrm{pdf}$

Chapleo, C. (2015). Brands in higher education: Challenges and potential strategies. International Studies of Management \& Organization, 45(2), 150-163. doi: 10.1080/00208825.2015.1006014

Chow, W. S., \& Chan, L. S. (2008). Social network and shared goals in organizational knowledge sharing. Information and Management, 45(7), 24-30.

Christensen, C. M., \& Eyring, H. J. (2011). The innovative university: Changing the DNA of higher education from the inside out (1st ed.). San Francisco, CA: Jossey-Bass.

Davcik, N. S., Vinhas da Silva, R., \& Hair, J. F. (2015). Towards a unified theory of brand equity: conceptualizations, taxonomy and avenues for future research. Journal of Product \& Brand Management, 24(1), 3-17. doi: 10.1108/JPBM-06-2014-0639

Delgado-Ballester, E., \& Munuera-Alemán, J. L. (2005). Does brand trust matter to brand equity?. Journal of Product \& Brand Management, 14(3), 187-196. doi: 10.1108/10610420510601058

Dzulkifli Abdul Razak, Ramli Mohamed, Shuhaida Md Noor, \& Ming Hock Chai. (2010). Transforming higher education for a sustainable tomorrow 2009: Laying the foundation. Pulau Pinang, Malaysia: Universiti Sains Malaysia.

Erdem, T., \& Swait, J. (1998). Brand equity as a signaling phenomenon. Journal of Consumer Psychology, 7(2), 131-157. doi: 10.1207/s15327663jcp0702_02

Erdem, T., \& Swait, J. (2016). The information-economics perspective on brand equity. Foundations and Trends ${ }^{\circledR}$ in Marketing, 10(1), 1-59. doi: 10.1561/1700000041

Fornell, C., \& Larcker, D. F. (1981). Evaluating structural equation models with unobservable variables and measurement error. Journal of Marketing Research, 18(1), 39. doi: $10.2307 / 3151312$

Furedi, F. (2011). Introduction to the marketisation of higher education and the student as consumer. In M. Molesworth, R. Scullion, \& E. Nixon (Eds.), The marketisation of higher education and the student as consumer (pp. 15-22). Oxford, England: Routledge. 
Gray, B. J., Shyan Fam, K., \& Llanes, V. A. (2003). Branding universities in Asian markets. Journal of Product \& Brand Management, 12(2), 108-120. doi: 10.1108/10610420310469797

Hair, J. F., Black, W. C., \& Babin, B. J. (Eds.). (2010). Multivariate data analysis (7th ed.). Upper Saddle River, NJ: Pearson.

Hair, J. F., Hult, G. T. M., Ringle, C., \& Sarstedt, M. (Eds.). (2014). A primer on partial least squares structural equation modeling (PLS-SEM). Thousand Oaks, CA: SAGE Publications.

Haja Mydin, A. K. (2013). Pembangunan metriks ekuiti jenama universiti [Developing a university's brand equity metrics] (Master's Dissertation, Universiti Sains Malaysia, Penang, Malaysia).

Haja Mydin, A. K., Shuhaida, M. N., Nor Hazlina, H., \& Kamaliah, S. (2014). Pembinaan metriks ekuiti jenama universiti [Constructing brand equity metrics for universities]. Jurnal Komunikasi: Malaysian Journal of Communication, 30(1), 1-21. doi: 10.17576/JKMJC-2014-3001-01

Hemsley-Brown, J., Melewar, T. C., Nguyen, B., \& Wilson, E. J. (2016). Exploring brand identity, meaning, image, and reputation (BIMIR) in higher education: A special section. Journal of Business Research, 69(8), 3019-3022. doi: 10.1016/j.jbusres.2016.01.016

Iqbal, M. J., Rasli, A. B. M., \& Hassan, I. (2012). University branding: A myth or a reality. Pakistan Journal of Commerce and Social Sciences, 6(1), 168-184.

Jarvis, D. S. L. (2014). Regulating higher education: Quality assurance and neo-liberal managerialism in higher education-A critical introduction. Policy and Society, 33(3), 155-166. doi: 10.1016/j.polsoc.2014.09.005

Javani, V. (2016). University branding: A conceptualizing model. International Journal of Academic Research in Business and Social Sciences, 6(4), 227-232. doi: 10.6007/IJARBSS/v6-i4/2100

Joseph, M., Mullen, E. W., \& Spake, D. (2012). University branding: Understanding students' choice of an educational institution. Journal of Brand Management, 20(1), 1-12. doi: $10.1057 / \mathrm{bm} .2012 .13$

Kamaruzzaman, A. M., \& Che Mahzan, A. (2017). Workplace health promotion (WHP): employees' behaviour on smoke-free policy at public university in Malaysia. Selangor, Malaysia: IIUM Press.

Keller, K. L. (2003). Strategic brand management: Building, measuring, and managing brand equity (2nd ed.). Upper Saddle River, NJ: Prentice Hall.

Keller, K. L. (2013). Strategic brand management: Building, measuring, and managing brand equity (4th ed.). Boston, MA: Pearson.

Keller, K. L. (2016). Reflections on customer-based brand equity: perspectives, progress, and priorities. AMS Review, 6(1-2), 1-16. doi:10.1007/s13162-016-0078-z

Kementerian Kewangan Malaysia [Ministry of Finance Malaysia]. (2017). Maklumat Bajet Kerajaan: Kementerian Pendidikan Tinggi [Government Budget Information: Ministry of Higher Education]. Retrieved March 12, 2018, from http://www.treasury.gov.my/pdf/bajet/maklumat_bajet_kerajaan/2017/b64.pdf

Krejcie, R. V., \& Morgan, D. W. (1970). Determining sample size for research activities. Educational and Psychological Measurement, 30(3), 607-610. doi: 10.1177/001316447003000308 
Lehmann, D. R., Keller, K. L., \& Farley, J. U. (2008). The structure of survey-based brand metrics. Journal of International Marketing, 16(4), 29-56. doi: 10.1509/jimk.16.4.29

Malaysian Qualifications Agency. (2018). Malaysian qualifications register. Retrieved August 26, 2018, from http://www2.mqa.gov.my/mqr/akrbyipts.cfm?StartRow=76

Md Noor, S., Styles, C., \& Cowley, E. (2011). Brand equity: Linking financial and customer perspectives. In M. Uncles (Ed.), Perspectives on brand management (pp. 22-39). Melbourne, Australia: Tilde University Press.

Newman, S., \& Jahdi, K. (2009). Marketisation of education: Marketing, rhetoric and reality. Journal of Further and Higher Education, 33(1), 1-11. doi: 10.1080/03098770802638226

Nunnally, J. C., \& Bernstein, I. H. (1994). Psychometric theory (3rd ed.). New York, NY: McGraw-Hill.

Pinar, M., Trapp, P., Girard, T., \& Boyt, T. E. (2014). University brand equity: An empirical investigation of its dimensions. International Journal of Educational Management, 28(6), 616-634. doi: 10.1108/IJEM-04-2013-0051

QS World University Rankings. (2018). QS world university rankings 2019 - Indicators. Retrieved November 25, 2018, from https://www.topuniversities.com/universityrankings/world-university-rankings/2019

Ramayah, T., Lee, J. W. C., \& In, J. B. C. (2011). Network collaboration and performance in the tourism sector. Service Business, 5(4), 411-428. doi: 10.1007/s11628-011-0120-z

Reynolds, T. J., \& Phillips, C. B. (2005). In search of true brand equity metrics: All market share ain't created equal. Journal of Advertising Research, 45(02), 171. doi: $10.1017 /$ S0021849905050191

Ringle, C., Wende, S., \& Becker, J. (2015). SmartPLS 3 (Version 3.2.7). Boenningstedt, Germany: SmartPLS GmbH.

Rohaniza Idris. (2016, August 8). 39,862 pelajar ditawarkan tempat di Universiti Awam (UA) $[39,862$ Students are offered a place at the Public University (PU)]. BH Online. Retrieved from https://www.bharian.com.my/node/181110

Sekaran, U., \& Bougie, R. (2010). Research methods for business: A skill-building approach (5th ed.). Chichester, England: Wiley.

Sultan, P., \& Yin Wong, H. (2012). Service quality in a higher education context: An integrated model. Asia Pacific Journal of Marketing and Logistics, 24(5), 755-784. doi: $10.1108 / 13555851211278196$

Sultan, P., \& Yin Wong, H. (2014). An integrated-process model of service quality, institutional brand and behavioural intentions: The case of a university. Managing Service Quality: An International Journal, 24(5), 487-521. doi: 10.1108/MSQ-012014-0007

Taib, F. M., \& Abdullah, M. N. L. Y. (Eds.). (2016). Governance reforms in public universities of Malaysia. Pulau Pinang, Malaysia: Penerbit USM.

Teeroovengadum, V., Kamalanabhan, T. J., \& Seebaluck, A. K. (2016). Measuring service quality in higher education: Development of a hierarchical model (HESQUAL). Quality Assurance in Education, 24(2), 244-258. doi: 10.1108/QAE-06-2014-0028 